\title{
GENETIC STUDIES ON YIELD, YIELD COMPONENTS AND FIBER PROPERTIES IN SEGREGATING GENERATIONS OF AN INTRASPECIFIC COTTON CROSS
}

\author{
EL-ADLY, H.H. AND ABEER S. ARAFA
}

\author{
Cotton Research Institute, ARC, Giza
}

(Manuscript received 13 December 2008)

\begin{abstract}
Estimation of gene action through partioning of genetic variance was carried out, using the parents, $F_{1}, F_{2}$ and $F_{3}$ populations in the cross Giza 90 $x$ Pima S62 (24202).

Results showed that the heterotic effects relative to better parent (useful heterosis) were positive and highly significant or significant for all studied characters except for First Fruiting Node (FFN), boll weight (BW), micronair value (Mic), Fiber strength (St) and Fiber elongation (Elon \%), while days to first flower (DFF) recorded highly significant better parent heterosis value. Mid-parent heterosis values were highly significant and negative for days to first flower (DFF) and boll weight (BW). On the other hand, the remaining traits revealed positive and highly significant or significant heterotic effects except for First Fruiting Node (FFN), lint percentage ( $\mathrm{L} \%$ ), micronair value (Mic) and Fiber elongating (Elon \%) which showed insignificant heterotic effects.

Inbreeding depression was positively significant and highly significant for all traits except for boll weight (BW), micronair value (Mic) and Fiber elongation (Elon \%). On the other hand First Fruiting Node (FFN) and days to first flower (DFF) recorded negatively significant inbreeding depression.

Regarding potence ratio, partial dominance values were obtained for all studied traits except for days to first flower (DFF), seed cotton yield/plant (SCY/P), lint yield/plant (LY/P), Fiber strength (St) and upper half mean length (UHM) which recorded over dominance.

Concerning the type of gene effects, the additive gene effects were negative and highly significant for days to first flower (DFF), Fiber strength (St) and upper half mean length (UHM), while lint yield/plant (LY/P), lint percentage (L\%) and Fiber elongation (Elon \%) showed positive significant and highly significant for additive gene effect. Dominance gene effects were positive and highly significant or significant for days to first flower (DFF), seed cotton yield/plant (SCY/P), lint yield/plant (LY/P), Fiber strength (St) and upper half mean length (UHM) and boll weight (BW), respectively. On other hand, Fiber elongation (Elon \%) trait showed highly significant negative dominance gene effect. Additive $\mathrm{x}$ additive gene type of epistasis effects were highly significant for seed cotton yield/plant (SCY/P), lint yield/plant (LY/P) and lint percentage (L\%), while first fruiting node (FFN), days to first flower (DFF), boll weight (BW), micronair value (Mic), Fiber strength (St), uniformity index (UI), upper half mean length (UHM), seed index (SI) and lint index (LI) recorded negatively highly significant and significant epistatic of gene effects. With regarded to the dominance $x$ dominance interaction, the values were positive and highly significant for all studied traits except for seed index (SI), lint index (LI) and uniformity index (UI).

High values of broad sense heritability (over 50\%) were detected for first fruiting node (FFN), boll weight (BW) and Fiber elongation (Elon \%). Moderate heritability estimates (between $30 \%$ and $50 \%$ ) were found for
\end{abstract}


seed cotton yield/plant (SCY/P), lint yield/plant (LY/P), seed index (SI), lint index (LI), micronair value (Mic), uniformity index (UI) and upper half mean length (UHM). Low broad sense heritability values (less than $30 \%$ ) were obtained for days to first flower (DFF), lint percentage ( $L$ \%) and Fiber strength (St). Narrow sense heritability estimates were calculated for lint index (LI), Fiber strength (St), uniformity index (UI) and upper half mean length (UHM), which exceeded $50 \%$ value. Moderate heritability estimates were observed for first fruiting node (FFN), seed cotton yield/plant (SCY/P) and lint percentage $(\mathrm{L} \%)$. On the other hand low heritability values in narrow sense were obtained for days to first flower (DFF), boll weight (BW), lint yield/plant (LY/P), seed index (SI), micronaire value (Mic) and Fiber elongation (Elon \%).

The expected genetic advance from selecting the desired $5 \%$ of $F_{2}$ population was 56.098, 71.687, 29.399 and 48.12 for first fruiting node (FFN), days to first flower (DFF), lint yield/plant (LY/P) Fiber elongation (Elon \%) and upper half mean length (UHM), respectively.

Regression of $F_{2} / F_{3}$ results exhibited high values for first fruiting node (FFN), seed cotton yield (SCY/P), lint yield/plant (LY/P), lint percentage (L $\%)$, uniformity index (UI) and upper half mean length (UHM), indicating that the higher values due to the additive genetic variance.

Positively highly significant or significant correlation coefficient was observed between days to first flower (DFF) with first fruiting node (FFN), seed cotton yield/plant (SCY/P) with boll weight (BW), lint yield/plant (LY/P) with seed cotton yield/plant (SCY/P), lint percentage (L\%) with lint yield/plant (LY/P), lint index (LI) with lint percentage (L\%) and Fiber strength (St), micronair value (Mic) with lint index (LI), Fiber elongation (Elon\%) with Fiber strength (St) and upper half mean length (UHM) with days to first flower (DFF), lint percentage (L\%) and uniformity index (UI). Negative significant or highly significant correlation coefficient were recorded between seed cotton yield/plant (SCY/P) with days to first flower (DFF), seed index (SI) with seed cotton yield/plant (SCY/P) and lint yield/plant (LY/P).

It could be concluded that the selection improvement of first fruiting node (FFN), seed cotton yield (SCY/P), lint percentage (L\%), seed index (SI), uniformity index (UI) and upper half mean length (UHM) traits could be achieved in early segregating generations, but the other traits need intensive selection in later generations.

\section{INTRODUCTION}

The progress of any breeding program depends on the available genetic variation, it is necessary that the materials under investigation should be subject to genetic analysis in order to find out the relative magnitude of various types of genetic variance.

The present investigation deals with the determination of the genetic parameters of the population i.e. partitioning of variance, heritability estimates and expected genetic advance upon selection for yield, yield components and fiber properties.

El-Disouqi et al (2000) observed that additive gene effects were significantly positive for seed cotton yield /plant, lint yield/plant and boll weight. Mohamed et al 
(2001) found that additive gene effects were significantly positive for number of bolls/plant, boll weight, seed cotton yield/plant and lint percentage. Whereas, high heritability value in broad and narrow sense and regression coefficients were noticed for boll weight. Also they reported that the expected genetic advance upon selection was high for boll weight and number of bolls /plant. El-adly (2004) reported that the additive gene effects were positively significant for boll weight, number of bolls /plant seed cotton yield/plant, lint yield /plant, Micronaire values and Upper half mean length .He reported that the expected genetic advance values from selecting the desired $5 \%$ of $F 2$ population were $25.1,42.1,46.45$ and 16.6 for boll weight, number of bolls /plant, seed cotton yield /plant and lint yield /plant, respectively. Herring et al., (2004) reported that the Micronaire value and fiber strength showed low heritability estimates of $h 2=0.14$ to 0.19 , while lint yield exhibited a very low heritability estimate of $h 2=0.03$. Fiber length and strength were correlated ( $r=$ $0.58^{* *}$ to $0.46^{* *}$ ) in all the three generations. Andy et al (2005) indecated that the fiber length, fiber strength and fiber fineness showed moderately to highly heritability estimates. Nazmy (2006) reported that the inbreeding depression was positive highly significant and significant for seed index and boll weight, meanwhile additive gene effects and additive $x$ additive type of epistatic gene effects were highly significant for seed cotton yield and lint yield.

The object of this investigation was to study the genetic behavior of yield and its components in a cross between the two varieties, Giza90 and Pima S62 (24202).

\section{MATERIALS AND METHODS}

The materials used in this study were cultivar Giza90 and variety Pima S62 (24202) (Gossypium barbadense L.). The methods used in this study started a cross between two genotypes in 2004 season at Giza Agriculture Experimental Station.

F1, F2 and F3 generations were obtained from hybrid and selfed seeds in 2005, 2006 and 2007 seasons, respectively at Seds Experiment Station of the Agriculture Research Center at Banie Saufe Governorate.

Each non-segregating growing generations (P1, P2 and F1) consisted of four rows, F2 and F3 contained 12 rows. Each row was $7.5 \mathrm{~m}$ long, $60 \mathrm{~cm}$ apart with spaced hills $75 \mathrm{~cm}$. All the agriculture practices were done according to the ordinary cotton culture.

The following measurements were carried out on individual plants in each of the parents, F1, F2 and F3 populations:

\section{A- Yield characters}

1- First fruiting node (FFN). 
2- Days to first flower (DFF).

3- Boll weight (BW). Average weight in grams of 10 bolls / plant.

4- Seed cotton yield/plant (SCY/P) in grams.

5- Lint cotton yield/plant (LY/P) in grams

6- Lint percentage ( $\mathrm{L} \%)$.

7- Seed index (SI) in grams.

8- Lint index (LI) in grams.

\section{B- Fiber properties}

- Fiber Physical properties

1- Upper half mean length (m.m) UHM and, Fiber uniformity index (UI) were determined using the fibrograph 630 according to (ASTM D: 1447-67).

2- Fiber strength and elongation percentage were determined on the Stelometer Tester according to the standard methods of (ASTM D: 1445-67).

3- Micronaire reading was estimated using Micronaire 275 instrument according to [ASTM D: 1448-2006].

All fiber properties were tested in cotton Technology Research Division labs, Cotton Research Inst. (C.R.I.). under constant conditions of temperature $\left(20+2^{\circ} \mathrm{C}\right)$ and relative humidity $(65+5 \%)$.

\section{Statistical and genetically analysis.}

\section{1- Estimates of gene effects:}

Five parameters, $m, d, h$, I and $L$ were given by the formula of Mather and Jinks (1971):

$$
\begin{aligned}
& \mathrm{m}=\mathrm{F}_{2}- \\
& \mathrm{d}=1 / 2(\mathrm{P} 1-\mathrm{P} 2) \\
& \mathrm{h}=1 / 6\left(4 \mathrm{~F}_{1}+12 \mathrm{~F}_{2}-16 \mathrm{~F}_{3}\right) \\
& -\quad-\quad- \\
& \mathrm{I}=\mathrm{P} 1-\mathrm{F}_{2}+1 / 2(\mathrm{P} 1-\mathrm{P} 2+\mathrm{h}) \\
& \quad-\quad- \\
& \mathrm{L}=1 / 3\left(16 \mathrm{~F}_{3}-24 \mathrm{~F}_{2}+8 F_{3}\right)
\end{aligned}
$$

Where:

$\mathrm{m}=$ constant mean.

$d=$ Pooled additive effects.

$\mathrm{h}=$ pooled dominance effects.

$\mathrm{I}=$ pooled interaction between additive by additive effects. 
$\mathrm{L}=$ pooled interaction between dominance by dominance effects.

\section{2- Heritability estimates:}

a. Heritability in broad sense (h2 b)

$$
\begin{aligned}
& V F_{2}-V E \quad 1 / 2 D+1 / 4 H \\
& h^{2} b=-1 / 2 D+1 / 4 \mathrm{H}+E \quad \text { (Allard, 1960) }
\end{aligned}
$$

Where:

$\mathrm{VE}=$ Environment variance calculated as the average of $\mathrm{P}_{1}, \mathrm{P}_{2}$ and $\mathrm{F}_{1}$

$V F_{2}=$ phenotypic variance in $F_{2}$

b. Heritability in narrow sense ( $h 2 \mathrm{n})$

$$
h^{2} n=\frac{1 / 2 D}{1 / 2 D+1 / 4 H+E}
$$

c. Parent - offspring regression, i.e. regression of $F_{3}$ line means on their corresponding $F_{2}$ plant values (b).

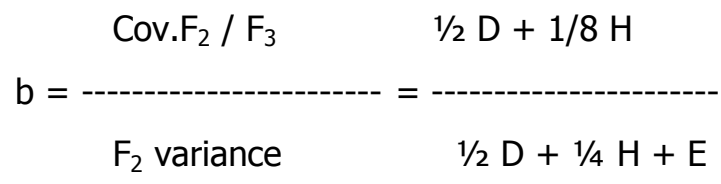

\section{3- Expected genetic advance under selection}

Genetic advance under selection was calculated according to Johanson et al (1955) as follows:

$$
\begin{aligned}
& \text { G.S. }=K \times \text { Ò } P \times h^{2} n- \\
& \text { G.S\% }=(G . S / F 2) \times 100
\end{aligned}
$$

Where:

G.S = expected genetic advance under selection.

$\mathrm{K}=$ selection differential with value of 2.06 under $5 \%$ selection intensity.

Ò $\mathrm{P}=$ Phenotypic stander deviation.

$h^{2} \mathrm{n}=$ heritability in narrow sense.

\section{4- Degree of dominance}

Potence ratio $(P)$ was calculated from the formula given by Smith (1952) to determine the degree of dominance.

$$
P=\overline{F_{1}}-M P /\left[1 / 2\left(P_{1}-P_{2}\right)\right] .
$$


Where:

$$
\begin{aligned}
& \bar{F}_{1}=\text { First generation mean. } \\
& \overline{P_{1}}=\text { Mean of the first parent. } \\
& - \\
& P_{2}=\text { Mean of the second parent. } \\
& \text { M.P }=\text { Mid parent value }=1 / 2\left(P_{1}+P 2\right)
\end{aligned}
$$

\section{5- Inbreeding depression}

Inbreeding depression\% (I.D \%) was determined as the percentage of decrease of $\mathrm{F} 2$ generation mean below the $F_{1}$ hybrid mean as follow:

$$
\begin{gathered}
\text { F1 }- \text { F2 } \\
\text { I.D \% = ------ } \\
\text { F1 }
\end{gathered}
$$

\section{RESULTS AND DISCUSSION}

Mean performances of yield and its components and coefficient of variation for Giza90, Pima $S 62$ (24202). $F_{1}, F_{2}$ and $F_{3}$ generations are presented in Table (1). The results showed that Pima S62 (24202), variety recorded higher mean values for SCY/P, LY/P, L\%, SI and UHM than Giza90. While Giza90 revealed higher values for FFN and DFF and for fiber Elon\% than Pima S62 (24202).

The results indicated that the mean performance of $F_{1}$ was higher than parents, $F_{2}$ and $F_{3}$ for DFF, SCY/P, LY/P, L \% and UI and exceeded the $P_{2}, F_{2}$ and $F_{3}$ for FFN trait.

It could be concluded from the results that the mean performance in $F_{2}$ and $F_{3}$ generations, the $F_{2}$ was higher value than their parents, $F_{1}$ and $F_{3}$ for SI and fiber St. The $F_{3}$ generation mean performance was higher than the parents and $F_{2}$ for $S C Y / P$, $\mathrm{LY} / \mathrm{P}, \mathrm{LI}$ and fiber Elon\% and exceeded all populations in DFF. Therefore selection could be effective in the improvement of the characters DFF, SCY/P, LY/P, LI and fiber Elon\% characters in the next generation. The data also revealed that the coefficient of variation of $F_{3}$ population was larger for FFN, DFF, L\%, SI and LI than their parents, $F_{1}$ and $F_{2}$ generations. This indicates that the environmental fluctuations have marked effects on the expression of these characters. 
Hetrosis, inbreeding depression and potence ratio are presented in Table (2). The values of heterosis versus the mid and better parents showed significant positive heterotic effects relative to mid and better parents were founed for all characters studied except for FFN, Mic and Fiber Elon\%. Significant negative heterosis relative to mid-parent and better parent for DFF. While L\% character showed significant positive heterotic effect relative to mid parent and fiber St for better parent. On the other hand, BW recorded negative heterosis effect to better parent.

Significant positive values of inbreeding depression (Table 2) were found for SCY $\backslash \mathrm{P}, \mathrm{LY} \backslash \mathrm{P}, \mathrm{L} \%$, SI, LI, fiber St, UI and UHM, indicating the accumulation of additive gene effects of the expression of these traits. However significant negative inbreeding depression values were noticed for FFN and DFF, suggesting that the genes controlling these traits were not completely segregated. The same results of heterotic effects were obtained by Disouqi et al (2000), Eissa (2004) and Nazmy (2006). On the other hand El-Disouqi et al (2000) showed significant negative inbreeding depression for SCY. Eissa (2004) recorded significant positive inbreeding depression for FFN.

Concerning potence ratio, Table(2) reveled over dominance for DFF, SCY $\backslash$, $\mathrm{LY} / \mathrm{P}$, fiber St and UHM traits, while the remaining traits exhibited positive or negative values of potence ratio less than unity indicating partial dominance effect.

Genetic parameters effects using generations means are shown in Table (6). The constant mean values $(\mathrm{m})$ were highly significant for all studied traits, it is clear that these traits were quantitavely by inherited. Additive genetic effects (d) were positive significant and highly significant for $L Y / P, L \%$ and fiber Elon\%, respectively. However it was highly significant and negative for DFF and UHM. On the other hand dominance gene effects $(h)$ were positive significant and highly significant for BW, DFF, SCY/P, LY/P, fiber St and UHM, while fiber Elon\% trait recorded negatively significant dominance gene effects (Table 4).The dominance genetic effects were larger than additive gene effects for most studied traits. This indicates that dominance genetic effects were more important in the inheritance of these traits. The additive $x$ additive type of epistasis (I) effects were highly significant and positive for SCY/P, $\mathrm{LY} / \mathrm{P}$ and $\mathrm{L} \%$ traits, the remaining traits revealed significant or highly significant epistasis gene effects. With regard to the interaction dominance $x$ dominance $(L)$ epistatic gene effects were highly significant and positive for most studied traits except for SI, LI and UI. From the above results, it could be concluded that the additive and dominance gene effects as well as some epistatic gene effects could have contributed to the inheritance of the studied traits. In this respect El-Helw Sayda (2002) and ElAdly (2004) obtained significant and highly significant additive $x$ additive type of epistasis effects for $L Y / P$ and $L \%$, while the interaction dominance $x$ dominance 
epistatic gene effects were negatively significant or highly significant for SCY/P, LY/P, Mic and UHM.

Heritability estimates in both broad and narrow senses, genetic advance upon selection as well as parent offspring (b) are presented in Table (5).the results showed that high broad sense heritability estimates (exceeded 50\%) were found for FFN, BW and fiber Elon\% characters. While moderate broad sense heritability estimates (30\% to $50 \%$ ) were detected for SCY/P, LY/P, SI, LI, Mic and UHM. On the other hand DFF, BW, L\% and Fiber St showed low broad sense heritability estimate (less than 30\%). High narrow sense heritability estimates were observed for LI, Fiber St, UI and UHM (more than 50\%). Moderate narrow sense heritability estimates were observed for FFN, SCY/P and L\%. Low narrow sense heritability estimates were recoded for DFF, BW, LY/P, fiber St, Mic and fiber Elon\%. From the above results it could be concluded that high heritability estimates in broad sense indicated that the selection for phenotype could be highly effective for FFN and BW traits. High narrow sense heritability could be due to the additive genetic effect for the characters LI, Fiber St, UI and UHM, selection for these traits will be effective in early generations.

The expected genetic advance upon selection at $5 \%$ of $F_{2}$ population in (Table 4) ranged from 5.678 for BW to 71.687 for DFF. The results of expected genetic advance upon selection were higher for FFN, DFF, LY/P, fiber Elon\% and UHM indicating that the improvement of these traits is highly effective through selection. Abou-Arab et al (1997) found that the expected genetic advance upon selection was higher for BW, SCY/P and LY/P.

Parent off spring correlation and regression are listed in Table (4). The high value of regression for FFN, SCY/P, L\%, UI and UHM suggested that the F2 plants which had high values tended to give F3 lines with high values. High value regression is usually due to the additive genetic variance.

Correlation coefficient between all possible pairs of studied traits are presented in Table (5). Highly significant and positive correlations were observed between DFF with FFN, LY/P with SCY/P, L\% with LY/P, LI with L\%, fiber Elon\% with Fiber St and UHM with DFF and UI. On the other hand significant positive correlation was detected between SCY/P with BW, LI with SI, Mic with LI and UHM with L\%. While negatively significant correlation was recorded between SI and LY/P.

It could be concluded that the improvement in this material of FFN, SCY/P, L\%, SI, UI and UHM traits could be achieved in early segregating generations, but the improvement of the other traits need intensive continuous selection through later generations. 


\section{REFERENCES}

1. Abo-Arab, A. R. A, A.F.Lasheen and Z.F. Abo-Sen 1997. Genatical analysis of yield and its components in Egyptian cotton. J. Agric. Sci. Mansoura Univ., 22 (11): 3675-3681.

2. Allard, R.w.1999. Princeples of plant breeding. Secnd edit. John Wiley \& Sons Inc., New Yourk, Lodon. U.S.A

3. Andy D., M. Lacape, T. B. Nguyen, B. Courtois, J. L. Bélot, M. Giband, J. P. Gourlot, G. Gawrysiak, S. Roques and B., Hau. 2005.QTL analysis of cotton fiber quality using multiple Grossypium hirsutum x Gossympium bardadense backcross generations. Crop science, 45 (1): 123-140.

4. American stander for testing materials (ASTM), D1447and D1445 (1967), D3818 (1986)., D1448(2006). USA.

5. El-Adly, H. H. 2004.Genetic studies on some quantitative characters in an intraspecific cotton cross of (G. barbadense.L). Egypt. J. Appl. Sci, 19 (11) 188198.

6. Eissa, A. E. M. 2004. Inheritance of some quantitative characters in two interval cotton crosses. Minia J.of Agric.Res.\& devolp., 24 (3) 367-380.

7. El Helow Sayda S. H. 2002. Genetic parameters for some economic characters in the extra long cotton cross (Giza 68 x Sea Island). J. Agric. Sci. Mansoura Univ. 27 (12), 8011-8020.

8. El-Disouqi, A.E., Z. F. Abo-Sen and A. R. Abo-Arab. 2000. Genetic behaviour of yield and its components in Egyptian cotton. J. Agric. Sci., Mansoura Univ., 25(7): 3831-3840.

9. Herring, A. D., Dick L. Auld, M. Dean Ethridge, Eric F. Hequet, E. Bechere, Cary J. Green and Roy G. Cantrell. 2004. Inheritance of fiber quality and lint yield in a chemically mutated population of cotton. Euphytica Volume 136, pp.333-339.

10. Johanson, H. W., H. F. Robinson and R. E. Comstock. 1955. Estimates of genetic and environmental variability in soybean. Agrion. J., 47: 314-318.

11. Mohamed S. A. S. , I. S. M. Hassan and G. M. Hemaida. 2001. Genetical studies on yield and some yield components in the Egyptian cotton cross, (Giza80 x Giza85). Annals of Agric. Sc., Moshtohor, Vol.39(2):751-761

12. Mather, K. and J. L. Jinks. 1971. Biometrical Genetics. Chapman and Hall, London, England

13. Nazmey, M. N. A. 2006. Genotype studies on some quantitative characters in an extra-long staple cotton cross. Egypt. J. Appl. Sci, 21(12B) 2006. 


\title{
دراسات وراثية على المحصول ومكوناته وصفات التيلة للاجيال الانعزالية في هجين صنفى من القطن
}

\author{
حسن حسين العدلى ، عبير سمير عرفه \\ معهز بحوث القطن - مركز البحوث الزراعية - جيزة
}

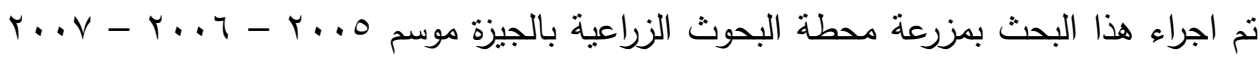

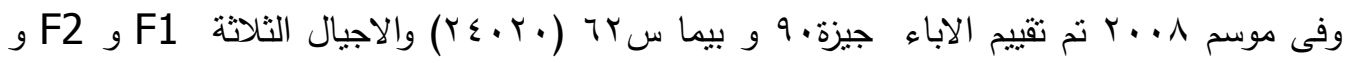

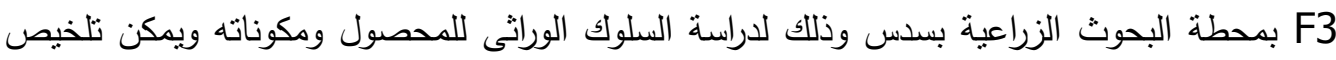

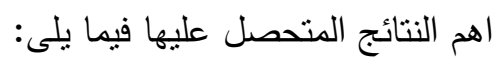
1. اثتت النتائج ان قوة الهجين منسوبة الى منوسط الابوين كانت معنوية وموجبه لجميع الصفات المدروسه عدا صفة ارتفاع عقدة اول فرع ثمرى ومتوسط وزن اللوزة وقرأة الميكرونير ومتانة التيله

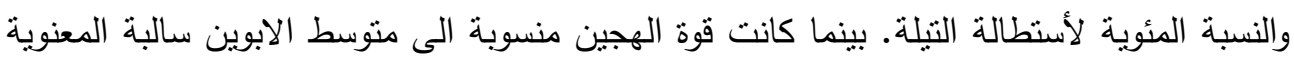

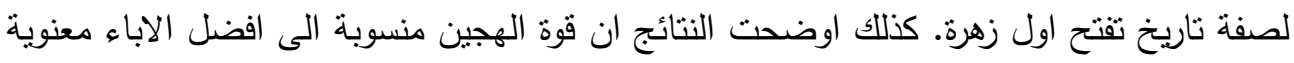
موجبه لكل الصفات المدروسه عدا صفة ارتفاع عقدة اول فرع ثرى وتصافى الحلى الحيج وقرأة

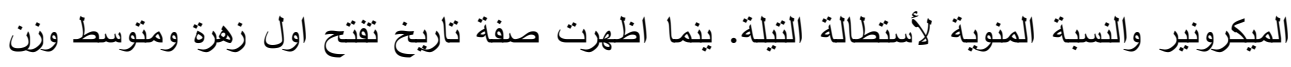

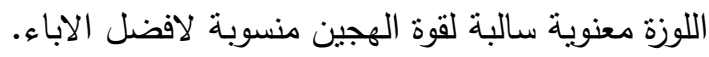

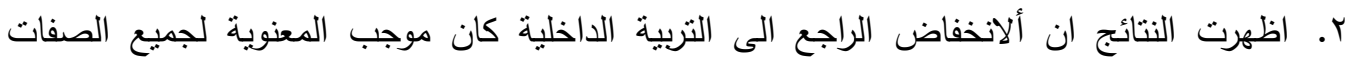

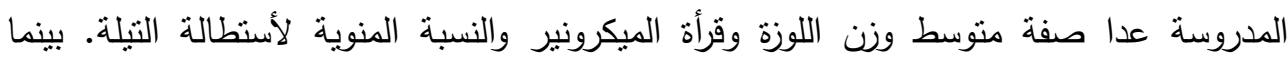
اظهرت صفة ارتفاع عقدة اول فرع ثمرى وتاريخ تقتح اول زهرة معنوية سالبة لمعامل التربية

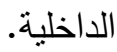
r. اوضحت النتائج ان كل الصفات المدروسة اظهرت سيادة جزئية عدا صفة تاريخ تفتح اول زهرة ومحصول القطن الزهر والثعر للنبات ومتانة التبلة و طول التبلة حيث اظهروا سيادة فائقة.

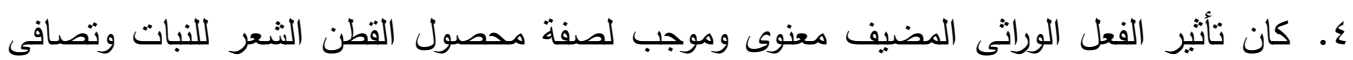
الحليج والنسبة المنوية لأستطالة التيلة بينما اظهرت صفة تاريخ تفتح اول زهرة ومثانة وطول التيلة معنوية سالبة للفعل الاضافى للجين. كذلك اظهرت صفة تاريخ تقتح اول زهرة ومتوسط وزن اللوزة

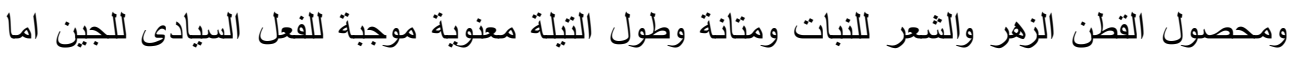

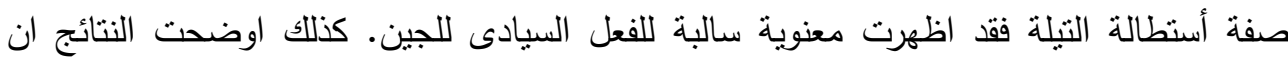
تأثثر تفوق الفعل الجينى الراجع الى الفعل الجينى المضيف × المضيف معنوى وسالب لمعظم

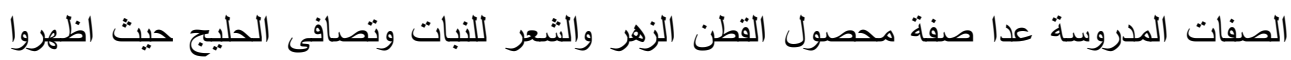

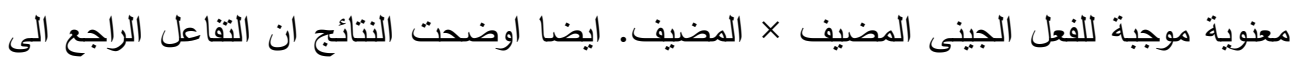
الفعل السيادى × السيادى للجين كان معنوى وموجب لكل الصفات المدروسة عدا صفة معامل البذرة ومعامل الثعر للنبات ومعامل انتظام التيلة. 
0. كانت قيم المكافئ الوراثى فى المعنى الواسع (اكبر من .0\%) عالية لكل الصفات المدروسة عدا

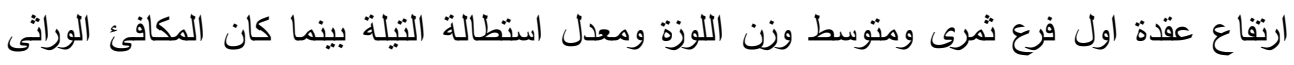
متوسطة (من •r\% الى •0\%) لصفة محصول القطن الزهر والثعر للنبات وتصافى الحليج ومعامل البذرة والثعر وقرأة الميكرونير ومتانة التيلة ومعامل انتظام التيلة و طول التيلة. بينما

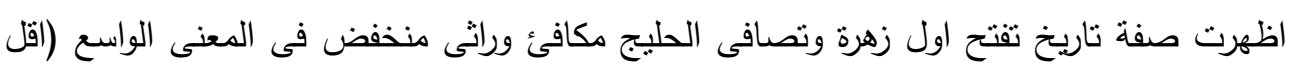

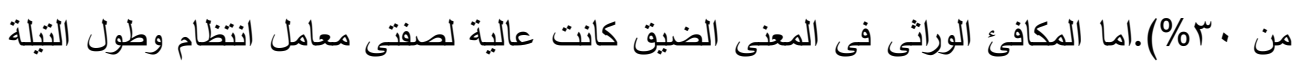

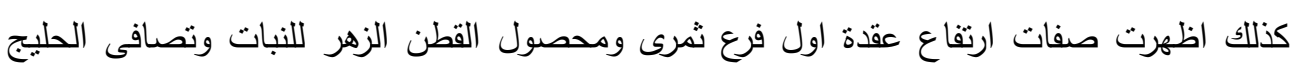

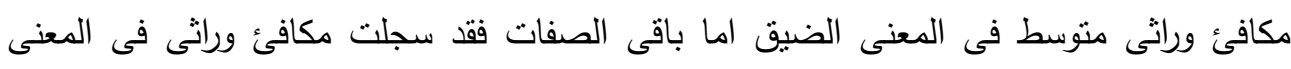
الضيق منخفضة. 7. اظهر التحسين المتوقع من الانتخاب قيم عالية لصفات ارتفاع عقدة اول فرع ثمرى وتاريخ تفتح اول

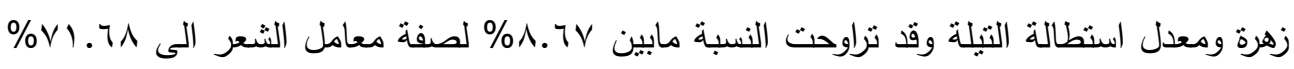
لصفة تاريخ تفتح اول زهرة. V. اظهرت النتائج ان هناك علاقة قوية بين النباتات فى الاجيال الانعزالية (الجيل الثانى والثالث) وان

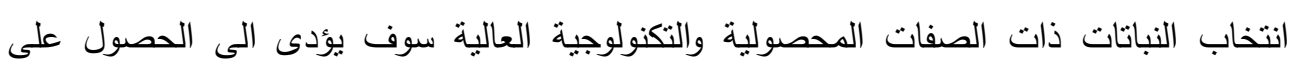
نباتات ممتازة فى الجيل الثالث.

^. اوضحت النتائج ان هناك علاقة معنوية وموجبة بين كل من تاريخ تفتح اول زهرة وارتفاع عقدة اول

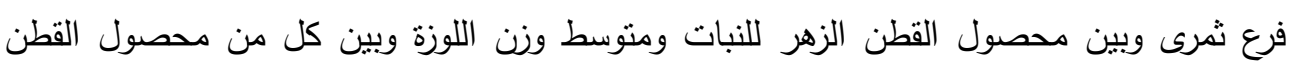

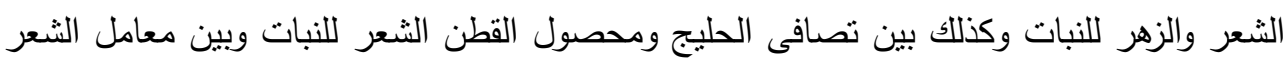
وكل من تصافى الحليج ومعامل البذرة كذلك كان الارتباط موجب بين استطالة ومتانة التنلة وكذللك

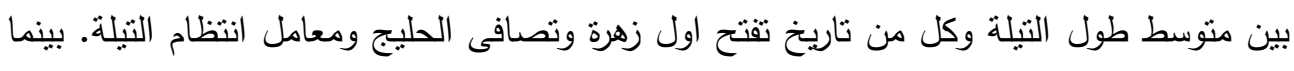
اظهرت النتائج ان هناك ارتباط معنوى وسالب بين كل من معامل البذرة ومحصول القطن الثعر 